\title{
EMERGING TRENDS IN REPORTING: AN ANALYSIS OF INTEGRATED REPORTING PRACTICES BY SOUTH AFRICAN TOP 40 LISTED COMPANIES
}

\author{
Ben Marx\# \\ University of Johannesburg \\ benm@uj.ac.za
}

Received: November 2013

\author{
Ahmed Mohammadali-Haji* \\ University of Johannesburg \\ ahmedh@pps.co.za
}

Accepted: March 2014

\begin{abstract}
Companies should behave as responsible corporate citizens and conduct their business in a manner that meets existing needs without compromising the ability of future generations to meet their needs. Thus they should protect, enhance and invest in the wellbeing of the economy, society and the natural environment in which they do business. Annual reporting format of financial reporting does not take cognisance of stakeholders' needs in this regard, and there is a need for reporting that brings together financial, sustainability, management commentary and governance aspects in a coherent, simplified and concise manner.

The objective of this paper is twofold: it aims, firstly, to provide a brief overview of the development of integrated reporting, and, secondly, to provide evidence regarding the integrated reporting practices at the largest listed companies in South Africa. This is done through a literature review of current corporate governance and sustainability developments, supported by empirical evidence obtained from assessing, through content analysis, the integrated reporting practices of the top 40 companies on the Johannesburg Securities Exchange, South Africa. The study found that although integrated reporting is evolving, inconsistencies still exist regarding the process to follow, format, content, and value thereof. The study is of specific relevance for Africa with its rich mineral resources, as it is of vital importance that companies that do business on the continent behave as responsible corporate citizens, respect the environment and society, and provide accurate, reliable and credible reporting on their financial and sustainability performance to all of their stakeholders in a simplified and integrated manner.
\end{abstract}

Keywords

Accounting; Corporate governance; Corporate citizenship; Integrated reporting; Sustainability reporting; JSE Top 40 companies

\#Prof B Marx is Head of Auditing, Department of Accountancy, University of Johannesburg, South Africa.

*Mr A Mohammadali-Haji is the Head of Accounting, Department of Accountancy, University of Johannesburg, South Africa. 


\section{INTRODUCTION}

Companies should behave as responsible corporate citizens and conduct their business in a manner that meets existing needs without compromising the ability of future generations to meet their needs. Thus they should protect, enhance and invest in the wellbeing of the economy, society and the natural environment in which they do business. It is also imperative that they provide relevant, reliable and accurate information to their various stakeholder groupings on the organisation's financial, sustainability, management and governance practices and performance.

Corporate governance developments over the years have given prominence to the need for organisations to do business in a responsible manner and respect the society and the environment in which it operates. From the earliest corporate governance reports to the most recent there has been a shift from a 'shareholder' focus to a more inclusive 'stakeholder' focus, and from profits for shareholders only to the recognition that organisations have a responsibility to those who give them their licence to operate, namely their stakeholders (Ackers, 2009:2; King, 2006:21; Marx, 2008:334; Marx \& Van der Watt, 2013; Mitchell, Curtis \& Davidson, 2008:67-69; Naidoo, 2009:246-250). There has also been an increased focus on sustainability and corporate citizenship, with the third King Report on Corporate Governance for South Africa (hereafter King III) of 2009 stating that 'Sustainability is the primary moral and economic imperative of the $21^{\text {st }}$ century and one of the most important sources of both opportunities and risks for businesses.' It further states that it is expected of entities to behave like corporate citizens, which is described as involving 'social, environmental and economic issues - the triple context in which companies in fact operate' (Institute of Directors (hereafter IoD), 2009:11-12).

The reporting of financial information through typical annual financial statements and other information in annual reports has come under scrutiny over the years and the view exists that fundamental changes need to be made to the current format of financial reporting to increase its relevance and stakeholder value. This requires a new form of reporting that integrates an organisation's social and environmental performance with its economic performance in a simplified manner (International Federation of Accountants (hereafter IFAC), 2011; Harvey, 2011; Roberts, 2012). Financial information was traditionally provided through the annual report, while non-financial reporting, which focuses on environmental, social, transformation, ethical, safety and health information, was provided as part of the annual report, or in a separate sustainability report (Marx \& Van der Watt, 2011). King III requires that sustainability reporting and financial and sustainability disclosure be integrated with the company's financial reporting (principle 9.2), based on the underlying notion that strategy, risk, performance and sustainability have become inseparable, and defines integrated reporting as 'the holistic and integrated representation of the company's performance in terms of both its finances and its sustainability' (IoD, 2009:121; Marx \& Van Dyk, 201la:108; Marx \& Van Dyk, 2011b:41-43; Roberts, 2012:11). The recommendation of King III regarding integrated reporting gave rise to the establishment of both the International Integrated Reporting Committee, as well as the South African Integrated Reporting Committee, both under the chairmanship of Mervyn King, with the aim of enhancing, consolidating and providing guidance on best practice for integrated reporting. The objective is that an integrated report should provide stakeholders with a concise overview of an organisation, integrating and connecting important information about strategy, risks and opportunities, and relating them to social, environmental, economic and financial issues (Integrated Reporting Committee of South Africa (hereafter IRC), 2011; International 
Integrated Reporting Committee (hereafter IIRC), 2011; loD, 2012; Marx \& Van der Watt, 2013; Terry, 2012).

The study found that although integrated reporting is evolving, inconsistencies still exist regarding the process to follow, format, content, and value thereof. The study is of specific relevance for Africa with its rich mineral resources, as it is of vital importance that companies that do business on the continent behave as responsible corporate citizens, respect the environment and society, and provide accurate, reliable and credible reporting on their financial, sustainability and governance performance to all of their stakeholders in a simplified and integrated manner.

The remainder of the paper is organised as follows. The next section presents the objectives, scope and limitations of the study. The sections that then follow describe the theoretical background of the paper, the methodology applied and the empirical findings and deductions. Recommendations drawn from the study are then provided, and conclusions are presented in the last section.

\section{OBJECTIVES, SCOPE AND LIMITATIONS}

The objective of the paper is twofold: it aims, firstly, to provide a brief literature overview of the development of corporate governance and its related aspects of corporate citizenship and sustainability, which gave rise to the need for integrated reporting; and, secondly, it aims to provide evidence on the integrated reporting practices at the largest listed companies in South Africa. This is done through a literature review of current corporate governance and integrated reporting developments, supported by empirical evidence obtained from assessing, through content analysis, the reporting practices of the Johannesburg Securities Exchange (hereafter JSE) Top 40 listed companies.

The study has two specific limitations: firstly, the assessment is limited to Top 40 JSE listed companies in South Africa, as defined by market capitalisation, and the findings might not necessarily be representative of the integrated reporting practices of smaller listed companies, unlisted entities or public sector institutions; and, secondly, this content analysis might have specific limitations, such as the risk of capturing an incomplete picture, as noted by Unerman (2000). However, content analysis is widely recognised and supported in the literature as a research instrument for analysing the characteristics of the population (Abeysekera, 2007; Ackers, 2009; April, Bosma \& Deglon, 2003; Barack \& Moloi, 2010; Boesso \& Kumar, 2007; Brennan \& Solomon, 2008; Dawkins \& Ngunjiri, 2008; Mirfazli, 2008; Stemler, 2001).

\section{LITERATURE REVIEW}

\subsection{Corporate governance, sustainability, stakeholder and corporate citizenship}

Corporate governance evolved since the separation of management and the ownership of companies took place with the formation of limited liability companies in the nineteenth century. This resulted in the directors being entrusted with management power, and shareholders needing to protect their investments against the abuse of power by the directors. 
The agency concept was thus created and the concept of corporate governance born (Marx \& Van der Watt, 2011; Pullinger, 1995; Reynecke, 1996). Corporate governance issues have been debated and discussed over the years for many reasons and in response to different circumstances. The debate has intensified since the 1990s as a result of business failures and corporate collapses, with various corporate governance codes being issued over the years that gave prominence to the need for businesses to behave in a responsible manner and to respect the society and the environment in which they do business. However, it was only with the release of the Cadbury Report on Corporate Governance in the United Kingdom in 1992 that the concept of corporate governance was widely recognised and formally defined. The modern definition of corporate governance is embedded in the Cadbury Report, which described corporate governance as 'the system by which companies are directed and controlled' (Cadbury Report, 1992:para. 2.5). The first report on Corporate Governance in South Africa (King I) was released in 1994 (IoD, 1994), and the first influential international corporate governance code was produced by the Organisation for Economic Co-operation and Development (OECD) in 1999. Today, corporate governance codes can be found all over the world in more than 90 markets. For corporate governance codes issued internationally, see the website of the European Corporate Governance Institute at http://www.ecgi.org/codes_/all_co_des.php.

Over the years various alternatives to the above definition of corporate governance have been suggested, but in essence it still remains the system by which companies are directed and controlled (Haskovec, 2012; Marx, 2008). The value of complying with sound corporate governance principles is profound, and brings many benefits for entities, their stakeholders and countries alike. Professor Michael Adams, Dean of the School for Law at the University of Western Sydney, expresses this as follows: 'countries and companies adopting corporate governance best practices are not guaranteed success, but provide evidence of a clear move towards sustainability and establishing long-term success' (Adams, 2012).

The concept of sustainable development, which led to the concept of sustainability, originated from the United Nations World Commission for Environment and Development Report (hereafter WCED), Our Common Future (commonly referred to as the Brundland Report), which defined sustainable development as 'development that meets the needs of the present without compromising the ability of future generations to meet their own needs' (Terry, 2008; WCED, 1987). The second Report on Corporate Governance for South Africa (hereafter King II) introduced the concept of sustainability into corporate governance (IoD, 2002, section 4), defining it as follows: 'This means that each enterprise must balance the need for long-term viability and prosperity - of the enterprise itself and the societies and environment upon which it relies for its ability to generate economic value - with the requirement for short-term competitiveness and financial gain'. King III, the most recent of the South African corporate governance reports issued to date, and hailed by Sir Adrian Cadbury as 'a charter for corporate citizenship', describes the sustainability of a company as: 'conducting operations in a manner that meets existing needs without compromising the ability of future generations to meet their needs. It means having regard to the impact that the business operations have on the economic life of the community in which it operates. Sustainability includes environmental, social and governance issues' (Cadbury, 2010; loD, 2009; Marx \& Van der Watt, 2011; Marx \& Van Dyk, 201la; Terry, 2012).

The concepts of stakeholder and corporate citizenship have developed over the years, with one of the first definitions of "stakeholder" being offered by Freeman (as quoted by Breckenridge, 2004), who defined stakeholders as 'any group or individual who can affect or is affected by the achievement of the organisation's objectives.' King II advocated a shift from the single bottom 
line of profits only, to a focus on corporate citizenship, sustainability and triple bottom line reporting (IoD, 2002; para. 41), while King III advocates a stakeholder-inclusive corporate governance approach that 'recognises that a company has many stakeholders that can affect the company in the achievement of its strategy and long term sustained growth' (IoD, 2009). The concept of corporate citizenship is based on the assumption that an organisation is a person and, like an individual citizen, should act with integrity and in a socially responsible manner (IoD, 2009; Maighan, Ferrell \& Hult, 1999; Marx \& Van der Watt, 2011; Marx \& Van Dyk, 201la; Smith, 1996). King III, as stated before, also requires integrated reporting of the company's performance in terms of its finances and its sustainability and set the process in motion for integrated reporting as discussed in section 3.2.

\subsection{Triple bottom line and integrated reporting}

Triple bottom line reporting (economic, social and environmental) has evolved over the years in reaction to stakeholder need for financial and non-financial information that expanded the traditional financial reporting framework to take into account an organisation's social and environmental performance in addition to its financial performance (Thornton, 2013; Wikipedia, 2013). Financial information is traditionally provided through an annual report, while sustainability information dealing with social and environmental aspects is provided through a sustainability report.

The corporate collapses of the past decade called into question the relevance and reliability of annual financial statements as a basis for measuring and reporting an organisation's performance and its ability to create and sustain value, especially in context of environmental, social and economic challenges. Similarly, sustainability reports have weaknesses, such as often being disconnected from the organisation's financial reports, being backward-looking and failing to make the link between sustainability issues and the organisation's core strategy. This gave rise to a new form of reporting, the integrated report, which enables stakeholders to evaluate an organisation's performance and to make informed assessments about its ability to create and sustain value. The integrated report should provide stakeholders with relevant, reliable and concise information on the organisation's strategy, risks, and opportunities and relate them to social, environmental, economic and financial issues (Deloitte, 2012; IRC, 2011; Terry, 2012; Matthews, 2011). Integrated reporting also bring many benefits such as influencing behaviour, bringing about integrated thinking and integrated management and cost savings as organisations re-invent and innovate on products and processes to meet their sustainability targets and make visible their use of and dependency on different resources and the organisation's access to and impact on them, which also ultimately affects the allocation of scarce resources. Integrated reporting should also reflect the integrated thinking of the board (IIRC, 2011; Hoffman, 2012; King, 2013; Terry, 2012).

\subsubsection{Definition of integrated reporting}

Various definitions of integrated reporting have been offered over the years, and various meanings ascribed to the term, but the most detailed and authoritative are those of the South African IRC and that of the IIRC.

The South African IRC defines integrated reporting as (IRC, 2011:6-7):

A report to stakeholders on the strategy, performance and activities of the organisation in a manner that allows stakeholders to assess the ability of the organisation to create and 
sustain value in the short-, medium- and long term. An effective integrated report reflects an appreciation that the organisation's ability to create and sustain value is based on financial, social, economic and environmental systems and by the quality of its relationships with its stakeholders. The integrated report should be written in clear and understandable language in order for it to be a useful resource for its stakeholders.

The International IRC defines integrated reporting as follows (IIRC, 2011:6-7):

\begin{abstract}
Integrated reporting brings together material information about an organisation's strategy, governance, performance and prospects in a way that reflects the commercial, social and environmental context within which it operates. It provides a clear and concise representation of how an organisation demonstrates stewardship and how it creates and sustains value.
\end{abstract}

From the above definitions it is clear that an integrated report is a concise report giving a holistic overview of the organisation, its performance and prospects against the background that it operates in, and how it creates and sustains value for its stakeholders.

\title{
3.2.2 South African perspective
}

The IRC was formed in May 2010 in South Africa to give guidance on good practice in integrated reporting. This followed the requirement of King III, issued in 2009, for integrated reporting of the company's performance in terms of its finances and sustainability. King III was also incorporated into the JSE listing requirements, which provided further stimulus for listed companies to provide integrated reporting on a comply or explain basis. A further development that contributed to the development of integrated reporting was the concession in the Companies Act, 2008, which allows for summarised financial statements, as well as electronic reporting, to shareholders. South Africa's IRC was the first in the world to issue draft guidance on a framework for integrated reporting when it released a discussion paper in January 2011. There are some areas of difference between the South African and the international discussion paper issued in September 2011; however, they are essentially the same in thought and guidance. The intention of the IRC is that local guidance will be aligned with the international guidance to promote international harmonisation (Graham, 2012; IRC, 2011, IIRC, 2011; IoD, 2012; Roberts, 2012; South African Institute of Chartered Accountants (hereafter SAICA), 2012a; 2012b; Terry, 2012; Vorster, 2012).

\subsubsection{International perspective}

The IIRC was launched in July 2010, and brought together global financial reporting standard setters and global sustainability reporting standard setters. The mission of the IIRC is to create a globally accepted integrated reporting framework that brings together financial, environmental, social and governance information in a clear, concise, consistent and comparable format. In September 2011 the IIRC released a Discussion Paper on a framework for an integrated report, titled Towards Integrated Reporting: Communicating Value in the $21^{\text {st }}$ Century. On 23 November 2012 the IIRC released a Prototype of the Integrated Reporting Framework and announced that it would release a formal draft version in April 2013, and a final version in December 2013 (IIRC, 2011; 2012; 2013; Gosling, 2013; Roberts, 2012; SAICA, 2012c; 2012d; Terry, 2012). 


\subsubsection{Content for integrated reporting}

At the time of writing this paper, the formal guidance available for the content of the integrated report is that of the South African IRC and the IIRC. As stated previously, these are essentially the same, and state that the integrated report should cover the following (IIRC, 2011):

\section{(a) Organisational overview and business model}

Focus: What the organisation does and how it creates and sustains value in the short, medium and long term.

This section is more internally focused and should cover:

- the organisation's mission, principal activities, markets, products and services;

- the business model, value drivers and critical stakeholder dependencies; and

- its attitude to risk.

(b) Operating context, including risks and opportunities

Focus: The circumstances under which the organisation operates, including the key resources and relationships on which it depends and the key risks and opportunities that it faces.

This section is more externally focused and should cover:

- the commercial, social and environmental context within which the organisation operates, including significant laws and regulations that affect the organisation's ability to create and sustain value in the short, medium and long term;

- the resources and relationships that are key to the organisation's success, including key stakeholders, their legitimate needs, interests and expectations, and their importance to the organisation; and

- the organisation's key risks and opportunities, including those that relate to its relationships and to its impact on, and the continued availability, quality and affordability of, relevant resources.

This builds on the high-level overview of the organisation and includes a more in-depth description of material issues and how they affect the organisation's ability to create and sustain value over time.

\section{(c) Strategic objectives and strategies}

Focus: Where the organisation wants to go and how it is going to get there.

This section describes the organisation's strategic objectives and its strategies to achieve those objectives. It sets out how the organisation will measure achievement and target outcomes for the short, medium and long term. It builds on the description of the organisational overview and operating context to provide report users with an understanding of what drives and protects the value of the organisation, and should identify the:

- risk management arrangements related to key resources and relationships;

- the linkage between strategies and other content elements; and

- what makes the organisation unique and able to realise value in the future. 


\section{(d) Governance and remuneration}

Focus: The organisation's governance structure, how it supports the strategic objectives, and how it relates to the organisation's approach to remuneration.

This provides insight into the organisation's oversight and tone at the top, and should include:

- an explanation of the organisation's leadership and strategic decision-making processes, including the skill set of those charged with governance;

- what actions those charged with governance have taken to influence the strategic direction of the organisation, including its culture, ethical values and relationships with key stakeholders; and

- how the remuneration of executives and those charged with governance is linked to performance in the short, medium and long term, including how it is linked to the organisation's use of, and impact on, the resources and relationships on which it depends.

\section{(e) Performance}

Focus: How the organisation performed against its strategic objectives and related strategies.

This section should include qualitative and quantitative information, including:

- key performance indicators and key risk indicators regarding the organisation's performance against its strategic objectives and related strategies;

- the organisation's impacts (both positive and negative) on the resources and relationships on which it depends;

- the significant external factors impacting performance; and

- how the organisation fared against its targets.

Information regarding financial performance should be integrated with information regarding performance with respect to the other capitals, as well as how innovation affects the ability of the organisation to create and sustain value. Performance information should also include a description of the organisation's view of its major external economic, environmental and social impacts and risks up and down the value chain, along with material quantitative information to the extent practicable.

The performance discussion in the integrated report should be more concise and connected, while referencing or linkages should be provided to other reports such as financial statements, a sustainability report or detailed website disclosures. The linkages between past and current performance and between current performance and future outlook should be made clear.

\section{(f) Future outlook}

Focus: What opportunities, challenges and uncertainties the organisation is likely to encounter in achieving its strategic objectives, and the implications of these for its strategies and future performance.

This builds on the information covered in sections one to five, and should highlight anticipated changes over time. It should also provide information about:

- how the organisation is currently equipped to respond to the operating context that it is likely to face in the future; 
- how the organisation balances short- and long-term interests;

- potential repercussions of where the organisation expects it will go in the short, medium and long term;

- the actions needed to get there; and

- the associated uncertainties.

The integrated report should also identify any real risks that could have extreme consequences, even though the probability of their occurrence might be considered quite small.

As these guidance principles were the most recent that were available for the financial periods covered in the empirical study (as discussed in section four), they were used as the basis for the content analysis of the integrated reports.

\section{METHODOLOGY}

The integrated reporting practices of the identified companies were empirically evaluated through content analysis of their annual reports, integrated reports and website reporting. The most recently available integrated reporting of the companies at the date of inspection (integrated reports, annual reports and website reports) were inspected between 1 and 15 March 2013. The integrated reporting practices of all the companies in the population were inspected (100\% coverage).

\subsection{Population}

The study focused on the integrated reporting practices at the largest listed companies in South Africa, and accordingly the largest 40 companies ranked by market capitalisation on the JSE's All-Share Index (referred to as the FTSE/JSE Top 40 Index (JSE, 2013a)) were selected as the population for the empirical study. This index represents the most significant part of the total market value of the JSE's All-Share Index, $83 \%$ in February 2013, and as such would represent a wide spectrum of stakeholders' interests in South Africa (JSE, 2013b). The names of the companies in the population are listed in Annexure A.

\subsection{Content analysis of reports}

As noted in section 2 of the paper, the use of content analysis to assess the integrated reporting practices of the companies is justified. This is further supported by Berelson (1952), Krippendorff (1980), Mouton (2005), Stemler (2001) and Weber (1990), who all agree that content analysis can be used for analysing documents and reports according to content categories based on rules of coding.

For the purpose of coding the integrated reporting practices, the following content analysis guidelines were used.

Guideline

FULLY DISCLOSED

NOT DISCLOSED

If the required information is fully If there is no disclosure of all the disclosed and appropriately described, required information, the item is the item is marked as Yes in the checklist. marked as No in the checklist. 


\subsection{Research control}

The research consisted of analysing the integrated reports, annual reports and website reporting of the selected Top 40 listed companies. The analysis was performed using a checklist against which the integrated reporting was measured. This checklist was developed from the literature review and informed by discussions with various knowledgeable people from commerce and industry, as well as academia. The results were tabled and the results confirmed by an independent adjudicator to ensure the quality and accuracy of the results obtained.

\section{RESEARCH FINDINGS AND INTERPRETATION}

This section presents details about the findings of the integrated reporting practices of the companies in the population.

TABLE 1: Type of reporting

\begin{tabular}{lcc}
\multicolumn{1}{c}{ Type } & Number & $\%$ \\
\hline $\begin{array}{l}\text { Integrated annual report (thus annual report and financial } \\
\text { statements combined) }\end{array}$ & 36 & 90.0 \\
Separate integrated report and annual report & 3 & 7.5 \\
Annual report only (thus no integrated report) & 1 & 2.5 \\
TOTAL & 40 & 100.0 \\
\hline
\end{tabular}

Source: Integrated report disclosure (own analysis)

Key interpretations based on the above findings:

The above findings indicate that almost all companies (90\%) prepared an integrated annual report - a single report combining the elements of integrated reporting with and within the traditional annual report, including the annual financial statements. Only three companies prepared a stand-alone integrated report as a separate document from their annual report. It was also evident that some companies merely renamed their annual report an integrated report, so as to seem to comply with the developments of integrated reporting and not seen to be left behind. One company did not provide any type of integrated reporting and cited compliance with the Listing Rules of SIX Swiss Exchange and the Listing Requirements of the JSE, to the extent that they apply to companies with secondary listings.

For the three companies with stand-alone integrated reports separate from their annual reports, the integrated report referred users to the companies' website where the integrated report, annual financial statements, sustainability report and other components of the traditional annual report were downloadable. However, these integrated reports were found to be in excess of 50 pages each. An assessment of the length of the reports of the 36 companies that prepared an integrated annual report also showed lengths in excess of 50 pages each.

The more detailed and pertinent issues relating to integrated reporting are further analysed and discussed in TABLES 2 to 4. 
TABLE 2 Scope and boundary

\begin{tabular}{|c|c|c|c|c|}
\hline & \multicolumn{2}{|c|}{ Number } & \multicolumn{2}{|c|}{$\%$} \\
\hline & yes & No & yes & No \\
\hline Materiality explained in the integrated report? & 9 & 31 & 22.5 & 77.5 \\
\hline Capitals described in the integrated report? & 5 & 35 & 12.5 & 87.5 \\
\hline $\begin{array}{l}\text { Clear and understandable language in the integrated } \\
\text { report? }\end{array}$ & 36 & 4 & 90.0 & 10.0 \\
\hline
\end{tabular}

Source: Integrated report disclosure (own analysis)

\subsection{Key interpretations based on the above findings:}

The above findings indicate that the majority of the companies (77.5\%) did not explain their materiality determination in their reports. An assessment of the companies that did explain their materiality basis showed that the explanations and bases were diverse, with some references to the traditional definition of materiality in accounting standards. There were also references in the context of sustainability reporting, for example, to the GRI G3 "self-test" methodology for materiality. These diverse interpretations of materiality make it difficult to compare and evaluate the significant matters arising in the different companies.

The fundamental concepts underpinning integrated reporting are considered to revolve around the various capitals that the organisation uses and affects. These capitals comprise financial, manufactured, human, intellectual, natural and social capitals. It is alarming to find that only a few companies (12.5\%) described their capitals in their reports. An assessment of companies not describing their capitals showed that the companies provided diagrams explaining their business model which gave more insight into the value chain, but did not articulate how the capitals are used and affected by the business model.

TABLE 3 Governance and assurance

\begin{tabular}{lcccc} 
& Number & & $\%$ \\
& yes & No & Yes & No \\
\hline $\begin{array}{l}\text { Governance body with oversight responsibilities for } \\
\text { integrated reporting identified? }\end{array}$ & 16 & 24 & 40.0 & 60.0 \\
$\begin{array}{l}\text { Basis used in preparing the integrated report } \\
\text { explained? }\end{array}$ & 27 & 13 & 67.5 & 32.5 \\
\begin{tabular}{l} 
Assurance provided on the integrated report? \\
\hline
\end{tabular} & 0 & 40 & 0.0 & 100.0 \\
\hline
\end{tabular}

Source: Integrated report disclosure (own analysis)

\subsection{Key interpretations based on the above findings:}

The above findings indicate that 16 companies (40\%) identified the governance body with oversight responsibility for integrated reporting. An assessment of these 16 companies showed 
that the governance bodies identified were either the board of directors or the audit and risk committees. This assessment also showed that statements of acknowledgement by the oversight bodies of the responsibility to ensure the integrity of the integrated report were found in only 10 of the 16 companies, while only five companies indicated that the board of directors had applied its collective mind to the integrated report. None of the 16 companies included an opinion or a conclusion on whether the report represented a reasonable or balanced view.

The basis used in preparing the integrated report was explained in 27 of the companies (67.5\%). This comprised mostly references to King III, with fewer references to the JSE Listing Requirements, Companies Act, Global Reporting Initiative and the Integrated Reporting Discussion Papers and isolated references to the South African Code for Reporting Mineral Resources.

None of the companies indicated that the integrated report had been independently and fully assured. However, an assessment of the reports showed that many companies made use of a combined assurance model comprising full and limited assurance over selected disclosures of the integrated report. These included the annual financial statements, the sustainability content and other selected non-financial disclosures. In the combined assurance model, some references were also made to various external accreditation, certification and assurance initiatives followed by the companies.

\section{TABLE 4 Content of the integrated report}

\begin{tabular}{|c|c|c|c|c|}
\hline & \multicolumn{2}{|c|}{ Number } & \multicolumn{2}{|c|}{$\%$} \\
\hline & yes & No & yes & No \\
\hline \multicolumn{5}{|l|}{ Organisation review and business model } \\
\hline Explanation of what the company does & 37 & 3 & 92.5 & 7.5 \\
\hline $\begin{array}{l}\text { Explanation of how the company creates and } \\
\text { preserves value in the short, medium and long term }\end{array}$ & 37 & 3 & 92.5 & 7.5 \\
\hline \multicolumn{5}{|l|}{ Operating context, including risks and opportunities } \\
\hline $\begin{array}{l}\text { Explanation of the circumstances under which the } \\
\text { company operates }\end{array}$ & 39 & 1 & 97.5 & 2.5 \\
\hline Explanation of the key risks the company faces & 33 & 7 & 82.5 & 17.5 \\
\hline Explanation of the key opportunities arising & 15 & 25 & 37.5 & 62.5 \\
\hline \multicolumn{5}{|l|}{ Strategic objectives and strategies } \\
\hline $\begin{array}{l}\text { Explanation of the company's short-, medium- and } \\
\text { long-term strategic objectives }\end{array}$ & 12 & 28 & 30.0 & 70.0 \\
\hline $\begin{array}{l}\text { Explanation of the strategies in place to achieve the } \\
\text { objectives }\end{array}$ & 28 & 12 & 70.0 & 30.0 \\
\hline \multicolumn{5}{|l|}{ Governance and remuneration } \\
\hline Explanation of the governance structure & 38 & 2 & 95.0 & 5.0 \\
\hline Explanation of how the governance structure & 16 & 24 & 40.0 & 60.0 \\
\hline
\end{tabular}


supports the company's strategic objectives, risk management and approach to remuneration

Performance

Explanation of how the company has performed against its strategic objectives and related 32 8

80.0 20.0 strategies

Future outlook

Explanation of the opportunities, risks, challenges and uncertainties the company is likely to encounter 35 5

87.5 12.5 in pursuing its strategic objectives

Explanation of the potential implications of the above for the company's strategies and future performance

Source: Integrated report disclosure (own analysis)

\subsection{Key interpretations based on the above findings:}

The above findings indicate that only a few companies in the population (37.5\%) explained their key opportunities arising. This might be due to the sensitive nature of such disclosures and possible loss of competitive advantage. The explanation of key risks was evident in the majority of the companies (82.5\%). However, it was found that some companies disclosed largely generic risks such as liquidity risk, price risk, etc. The above findings further indicate that few companies $(30 \%)$ are explaining their strategic objectives and strategies. This is alarming, as the concept of strategy is central and fundamental to integrated reporting.

While the above findings indicate that the explanations of the governance structures were evident in almost all companies (95\%), the explanations connecting the governance structure with its actions, particularly with respect to strategy, risk management, cultural and ethical values, innovation and its approach to remuneration, were found to be present in only $40 \%$ of the companies. This raises questions about whether companies are utilising integrated reporting as an opportunity to reassess their risks, strategy, performance and governance practices.

An assessment of the $30 \%$ of the companies that explained the potential implications of the opportunities, risks, challenges and uncertainties for the companies' strategies and future performance revealed that such explanations attended to external factors, risks and opportunities, with a detailed analysis of how these affect the achievement of strategic objectives. There were better explanations of the future availability, affordability and quality of the capitals, specifically mineral and other scarce resources, with projections and sensitivity analyses.

\section{RECOMMENDATIONS}


From the findings of the study it is recommended that companies carefully consider their current state and format of reporting and communication with their various stakeholders, and the integrating reporting currently applied by them. Companies are advised to approach integrated reporting not merely as a "new form" of reporting, but to utilise it as a valuable opportunity to reassess their risks, strategy, performance and governance practices. It is further recommended that companies should follow the guidance of the International Guideline on Integrated Reporting when drawing up their integrated reports.

It is also recommended that an analysis similar to the one undertaken here be performed once the final Integrated Reporting Framework is issued in order to assess its impact on companies' integrated reporting practices. It is further recommended that future research focus on the integrated reporting practices at smaller companies and public sector entities.

\section{CONCLUSION}

In conclusion, the study found that the integrated reporting of the selected companies varies from excellent to poor. It was also evident that some companies merely renamed their annual report to an integrated annual report, so as to seem to comply with the developments of integrated reporting and not to be seen to be left behind. It was further found that the form and content of integrated reporting still vary widely, and that the need for compliance with uniform reporting standards exists.

These findings are of significance, as they provide evidence of the current integrated reporting practices in South Africa, lend support to the recommendations of King III and the Integrated Reporting Committee that companies should provide integrated reporting on their business processes, financial, sustainability and governance performance, and also indicate the need for conformity with uniform reporting practices. The study is of specific relevance for Africa with its rich mineral resources, as integrated reporting aims to promote change in corporate behaviour, to inform resource allocation that supports short- and long-term value creation, to catalyse a cohesive and comprehensive approach to corporate reporting and to enhance accountability and stewardship regarding the use of organisational resources.

\section{LIST OF REFERENCES}

Abeysekera, I. (2007). Intellectual capital reporting between a developing and developed nation. Journal of Intellectual Capital, 8(2), pp. 329-345.

Ackers, B. (2009). Corporate social responsibility assurance: how do South African publicly listed companies compare? Meditari Accountancy Reseach, 17(2), pp. 1-17.

Adams, M. (2012). Global trends in corporate governance. Boardroom, March:16-19.

April, K.A., Bosma, P. \& Deglon, D.A. (2003). IC measurement and reporting: establishing a practise in SA mining. Journal of Intellectual Capital, 4(2), pp. 165-180.

Barack, K. \& Moloi, T. (2010). Assessment of Corporate Governance Reporting in the Annual Reports of South African Listed Companies. The South African Journal of Accountability and Auditing Research, 10(1), pp. 19-28.

Berelson, B. (1952). Content Analysis in Communication Research. Glencoe, Illinois: Free Press. 
Boesso, G. \& Kumar, K. (2007). Drivers of corporate voluntarily disclosure: A framework and empirical evidence from Italy and the United States. Accounting, Auditing and Accountability Journal, 20(2), pp. 269-296.

Breckenridge, R.G. (2004). Modelling ethical corporate governance in terms of the King Report. Project report submitted to the Faculty of Commerce, Law and Management in partial fulfilment for the degree of Master of Business Administration. Johannesburg: University of the Witwatersrand.

Brennan, N. \& Solomon, J. (2008). Corporate governance, accountability and mechanisms of accountability: an overview. Accounting, Auditing \& Accountability, 21(7), pp. 885-906.

Cadbury, A. (2010). Governance: Yesterday, Today and Tomorrow. Directorship, March:26-27.

Cadbury Report. (1992). Report of the Committee on the Financial Aspects of Corporate Governance. London: Gee (a division of Professional Publishing Ltd). ISBN 085258915.

Dawkins, C. \& Ngunjiri, F.W. (2008). Corporate Social Responsibility Reporting in South Africa. Journa/ of Business Communication, 45(3), pp. 286-307.

Deloitte. (2012). Integrated Reporting: Navigating your way to a truly Integrated Report. Deloitte \& Touche. Johannesburg, South Africa.

Graham, M. (2012). Integrated Reporting in South Africa - First Steps. Research on 2011 reports. College of Accounting, University of Cape Town. (Updated 18 September 2012). Cape Town, South Africa.

Gosling, P. (2013). IR Moves Forward. Accounting and Business, January:11-12.

Harvey, F. (2011). Sustainability developments. Reporting. Ernst \& Young, EYGM Limited.

Haskovec, N. (2012). Codes of Corporate Governance. Milstein Centre for Corporate Governance and Performance. Yale School for Management, Yale. (Working Paper).

Hoffman, M. (2012). Integrated Reporting in practise: The South African story. KPMG. RRD-268931.

[Online] Available: www.kpmg.com/integratedreporting. (Accessed 13 August 2012).

International Federation of Accountants. (IFAC). (2011). Key business leaders from around the world recommend fundamental changes to business reporting in IFAC report. [Online] Available:

https://mail.uj.ac.za/owa/?ae=Item\&1=IPM.Note\&id+RgAAAACLilfzRjEASZdmFnvhN. (Accessed 3 November 2011).

Integrated Reporting Committee of South Africa. (IRC). (2011). Framework for Integrated Reporting and the Integrated Report. Integrated Reporting Committee of South Africa. Johannesburg.

International Integrated Reporting Committee, (IIRC). (2011). Towards Integrated Reporting: Communicating Value in the $21^{\text {st }}$ Century. International Integrated Reporting Committee. London

International Integrated Reporting Committee, (IIRC). (2012). Integrated Reporting: Draft outline of the Framework for publication. International Integrated Reporting Committee. London

International Integrated Reporting Committee, (IIRC). (2013). Integrated Reporting: Working Draft of Prototype Framework. International Integrated Reporting Committee. London

Institute of Directors. (IoD). (1994). King / Report on Corporate Governance. Institute of Directors in Southern Africa. Johannesburg, South Africa.

Institute of Directors. (IoD). 2002. King // Report on Corporate Governance, Institute of Directors in Southern Africa. Johannesburg, South Africa. 
Institute of Directors. (IOD). (2009). King Report on Corporate Governance for South Africa. Institute of Directors in Southern Africa, Johannesburg, South Africa.

Institute of Directors. (IoD). (2012). The Integrated Report. Practice Notes. Institute of Directors in Southern Africa, Johannesburg, South Africa.

JSE Limited. (JSE). (2013a). FTSE/JSE Equally Weighted Top 40 Index. [Online] Available:

http://www.jse.co.za/Products/FTSE-JSE/IndicesBrochures.aspx. (Accessed 16 February 2013).

JSE Limited. (JSE). (2013b).MarkR@jse.co.za. 18 February 2013. Top 40 Index Performance.x/sx; Top 40 Costituents.x/sx. Email to marxb@mweb.co.za.

King, M.E. (2006). The Corporate Citizen. Johannesburg: Penguin Books (South Africa) (Pty) Ltd. ISBN 0143025082 .

King, M. દ. (2013). Mervyn King of the IIRC. The future of corporate reporting: towards a common vision. Kpmg International.

Krippendorff, K. (1980). Content Analysis: An Introduction to its Methodology. Newbury Park. CA: Sage.

Maighan, I, Ferrell, O.C., Hult, G.T.M. (1999). Corporate Citizenship: Cultural Antecedents and Business Benefits. Journal of the Academy of Marketing, 27(4), pp. 455-469.

Marx, B. (2008). An analysis of the development, status and functioning of audit committees at large listed companies in South Africa. DComm thesis. Johannesburg: University of Johannesburg.

Marx, B. \& Van der Watt, A. (2011). Sustainability and integrated reporting: an analysis of the audit committee's oversight role. Journal for New Generation Science, 9(2), pp. 56-71.

Marx, B. \& Van der Watt, A. (2013). Sustainability in accounting education: an analysis of the teaching thereof at accredited South African universities. SA Journal of Accounting Research, 27 (2013)

Marx, B. \& Van Dyk, V. (2011a). Sustainability reporting at large listed public sector entities in South Africa. SA Journal of Accounting Research, 23(1), pp. 103 -127.

Marx, B. \& Van Dyk, V. (2011b). Sustainability reporting and assurance: an analysis of assurance practices in South Africa. Meditari Accountancy Research, 19(1), pp. 39-55.

Matthews, D. (2011). Introducing Integrated Reporting. Performance insight through Better Business Reporting. Issue 1. KPMG.

Mitchell, M., Curtis, A. \& Davidson, P. (2008). Evaluating the process of triple bottom line reporting: Increasing the potential for change. Local Environment, 13(2), pp. 67-87.

Mirfazli, દ. (2008). Evaluate corporate social responsibility disclosure at Annual Report Companies in multifarious group of industry members of Jakarta Stock Exchange (JSX), Indonesia. Social Responsibility Journal, 4(3), pp. 388-406.

Mouton, J. (2005). How to succeed in your master's and doctoral studies. A South African guide and resource book. Pretoria: Van Schaik.

Naidoo, R. (2009). Corporate Governance - An Essential Guide for South African Companies. Durban: LexisNexis. ISBN 9780409046052.

Pullinger, A. (1995). The financial aspects of corporate governance in South Africa. MComm research report. Johannesburg: University of the Witwatersrand. 
Reynecke, M. (1996). Effective Corporate Governance - A South African Perspective. Raurek Bulletin, 5(6), pp. 34-39.

Roberts, L. (January 2012). Integrated reporting: the status quo. Accountancy SA (ASA):11-12.

Smith, N.C. (9 August 1996). Corporate Citizens and Their Critics. New York Times, page 11.

South African Institute of Chartered Accountants. (SAICA). (2012a). Significant changes in the way in which JSE listed companies report. Media release 23 October 2012. Kengray, Johannesburg.

South African Institute of Chartered Accountants. (SAICA). (2012b). South Africa's leading global role in corporate reporting. Media release 2 August 2012. Kengray, Johannesburg.

South African Institute of Chartered Accountants. (SAICA). (2012c). I/RC Releases Prototype of the International Framework. Press release 26 November 2012. Kengray, Johannesburg.

South African Institute of Chartered Accountants. (SAICA). (2012d). I/RC Releases Draft Outline of Integrated Reporting Framework. Email from Mathapelo_More@saica.co.za. 12 July 2012.

Stemler, S. (2001). An overview of content analysis. Practical Assessment, Research \& Evaluation, 7(17). [Online] Available: http://PAREonline.net/getvn.asp?v=7\&n=17. (Accessed 16 February 2011).

Terry, G. (2008). Green. The South African Institute of Chartered Accountants. Kengray. South Africa.

Terry, G. (2012). Green II. The South African Institute of Chartered Accountants. Kengray. South Africa.

Thornton, S. (2013). What is Triple Bottom Line Reporting? eHow. [Online] Available: http://www.ehow.com/about_5064070_triple-bottom-line-reporting.html. (Accessed 2 March 2013).

Unerman, J. (2000). Methodological issues - Reflections on quantification in corporate social reporting content analysis. Accounting, Auditing \& Accountability Journal, 13(5), pp. 667-681.

Vorster, S. (2012). What is Integrated Reporting? BusinessBrief, March:26.

Weber, R.P. (1990). Basic Content Analysis, $2^{\text {nd }}$ edition. California: Newbury Park.

Wikipedia. (2013). Triple bottom line. [Online] Available:

http://en.wikipedia.org/wiki/Triple_bottom_line. (Accessed 2 March 2013).

World Commission for Environment and Development. (WCED). (1987). Our Common Future [The Brundland Report]. 0xford. UK: Oxford University Press. 


\section{ANNEXURE A:}

Names of the companies in the population

Anglo American

Anglo American Platinum

Anglogold Ashanti

Aspen Pharmacare Holdings

African Rainbow Minerals

Absa Group

Assore Ltd

BHP Billiton

British American Tobacco

Bidvest Group

Compagnie Financiere Richemont

Capital Shopping Centres Group

Exxaro Resources

Firstrand

Gold Fields

Growthpoint Properties

Impala Platinum Holdings

Investec

Imperial Holdings

Kumba Iron Ore

Mediclinic International

Mondi

Mr Price Group

Massmart Holdings

MTN Group

Nedbank Group

Naspers

Old Mutual

Remgro

RMB

SABMiller 
Standard Bank Group

Steinhoff International

Shoprite

Sanlam

Sasol

Tiger Brands

Truworths International

Vodacom Group

Woolworths Holdings

Source: JSE 16 February 2013: Indices: FTSE/JSE CAP 40 
Marx \& Mohammadali-Haji 